\title{
Humic acids trigger the weak acids stress response in maize seedlings
}

\author{
Daiane Carvalho Baía', Fábio L. Olivares ${ }^{1}$, Daniel B. Zandonadi², Cleiton de Paula Soares ${ }^{1}$, Riccardo Spaccini ${ }^{3}$ \\ and Luciano P. Canellas ${ }^{1 *}$ (1)
}

\begin{abstract}
Background: Plants primed by humic acids showed physiological and molecular response against different abiotic stresses without the presence of stressor agents (salinity, drought, heavy metal toxicity). It is plausible that humic acids themselves can act as chemical priming substances in plants. We hypothesized that humic acids can trigger the weak acids stress response in cell plants acidifying the cytosol and thus eliciting the transduction signalling response cascade.

Methods: The dose-response curves of maize seedlings roots with different concentrations of humic, acetic and salicylic acids determined the most active and inhibitory concentration. These data were further used to evaluate changes on intracellular pH using BCECF-AM probe (2,7-bis(2-carboxyethyl)-5(and 6)-carboxyfluorescein, acetoxymethyl ester) and differential transcription level of genes related to weak stress response in plants by qPCR real time.

Results: Humic acids like short chain organic acids decrease the intracellular pH showed by the increased fluorescence of BCECF probe. The drop in cytosolic pH promoted by humic acids was not transient. We observed a high level of protein kinases related to cell energy-sensing and transcription factors associated to transduction of stress signalling.
\end{abstract}

Conclusion: The humic acids can be considered as a chemical priming agent, since in the appropriate concentration they can induce the typical plant abiotic stress response of weak acids inducing plant acclimation and enhancing the abiotic stress tolerance.

Keywords: Cell acidification, Humic substances, Phosphorylation, Signalling cascade

\section{Background}

The growing use of humic substances as plant growth promoter has attracted attention due to its effects on efficiency on nutrients use, crop quality and protection against abiotic stresses [1-8]. Abiotic stresses are one of the crucial constraints to food security and crop production. The increases in frequency of extreme

\footnotetext{
*Correspondence: lucianocanellas@gmail.com

${ }^{1}$ Núcleo de Desenvolvimento de Insumos Biológicos para a Agricultura da Universidade Estadual do Norte Fluminense Darcy Ribeiro, Ave Alberto Lamego 2000, Campos dos Goytacazes CEP 28013-602, Brazil

Full list of author information is available at the end of the article
}

environmental events in many regions of the world [9] highlight the importance of crop protection for the economies based on agricultural commodities.

The application of chemical stress priming agents represents a promising approach to manage the adaptation of plants to adverse field conditions, activating their adaptation mechanisms to environmental disturbances [10]. A number of chemical agents such as ethanol, mandipropamid, melatonin, polyamines, and sodium nitroprusside have been used to enhance abiotic stress tolerance in plants [11]. Humic acids can be also used as natural chemical prime agent. It was observed that seedlings primed by humic acids improve their resilience to main abiotic stress including salt, 
drought, heavy metal toxicity and humic substances themselves [12]. These seedlings showed general physiological adjustment and transcriptomic analysis unveil specific gene response against abiotic stress [12] in typical acclimation behaviour [13]. However, the main mechanisms underpinning the priming activity of humic acids on plant seedlings remain unclear.

Humic substances are made-up through a selforganization of natural molecules derived from SOM dynamic processes $[14,15]$, miming the behaviour of (bio)chemical complex system [16]. The association of humic molecules are hence composed from chemically protected domains of highly hydrophobic materials, surrounded by or contiguous with hydrophilic moieties held together by weak dispersive forces [14]. At a fixed $\mathrm{pH}$ value humic acids appear as supramolecular particles with a conic shape and a hole in the centre suggesting a pseudo-amphiphilic nature, with secluded hydrophobic domains and polar subunits in direct contact with hydrophilic exterior [17]. The selforganization of humic acid in solution can be viewed as an emergent characteristic resulting from the interaction of hydrophobic/hydrophilic domains with the aqueous medium [18]. Thus, it is plausible that molecules released from humic superstructures may then access cell membranes and induce different physiological responses like hormone auxins $[19,20]$, gibberellins $[21,22]$, cytokinins [23, 24], alkamides [25], nitric oxide $[26,27]$. This is the well-founded hormonal hypothesis for the physiological effects of humic substances [28]. If on the one hand the presence of specific molecules like hormones embracing into the hydrophobic cage can access cell receptors, on the other hand the external shape resulting from emergent association with hydrophilic domains facing the outer face of the solution can promote cell modifications.

The main chemical groups containing hydrophilic properties are the phenolic and carboxylic groups with ubiquitous presence in the humic matters. In this respect, it has to be noticed that the major part of the plant hormones has acid functionalities. In previous studies a prevalence of carboxyl carbon groups, phenolic moieties and sugars was detected in the larger bioactive fraction of humic acids isolated from different sources, such as recycled biomasses [29-31].

Humic acids have a high degree of interaction with organic compounds that occur naturally in the soil. Such interactions can directly influence the physical-chemical characteristics and aspects related to structural characteristics such as functionality, reactivity and its effect on agricultural use. Organic acids are capable of crossing the cell membranes and act as one of the most ancient food and beverage preservatives due their direct effect on microorganisms. In fact, the carboxylic groups in organic acids are responsible for the well-known effect in microorganisms denoted as the weak acid stress. The weak acids stress mechanisms were described in general terms as the inhibitory effect imposed on microorganisms due to the 'uncoupling' mechanism [32]. At low $\mathrm{pH}$, weak acids prevail in undissociated form, being more hydrophobic and prone to crossing the membrane by simple passive diffusion. Once inside the cell, weak acids will dissociate in the near-neutral cytosol and release protons, which can potentially acidify the cell and cause dissipation of the proton-motive force [32].

The application of acetic acid directly in plants enhanced drought tolerance in Arabidopsis, rice, maize, rapeseed, and wheat by activating the jasmonate (JA)signalling pathway [33]. The use of acetic acids as prime chemical agent aiming drought tolerance was also observed in perennial plants like cassava [34]. In addition, is well known that salicylic acid is involved in activation of secondary metabolism and plant defence attributed to redox regulations in plant cells and activation of JA-signalling pathway [35]. Moreover, chemical functional analogues of salicylic acids were used in the crop protection [36].

The objective of this work was to evaluate the biochemical effects of humic acids in plants under stress conditions, comparing their action on cell $\mathrm{pH}$ using the fluorescent probes BCECF-AM (2',7'-bis- $(2-$ carboxyethyl)-5-(and 6)-carboxyfluorescein(-acetoxymethyl ester) with the effects caused by other organic acids: acetic and salicylic acids. The characteristics of the root were evaluated, as well as some molecular markers related to the weak acid stress response in order to explain the response mechanisms.

\section{Materials and methods}

\section{HA extraction and characterization}

Humic substances was extracted from vermicompost produced with cattle manure with $0.1 \mathrm{~mol} \mathrm{~L}^{-1} \mathrm{NaOH}$ 1:10 (v:v), under an atmosphere of $\mathrm{N}_{2}$ for $4 \mathrm{~h}$ followed by centrifugation $(3000 \times g)$. The extraction procedure was repeated until the extracts presented zero absorbance at 280 and $465 \mathrm{~nm}$. The separation of humic acids from the alkaline extract was obtained by acidification at $\mathrm{pH} 1$ with $6 \mathrm{~mol} \mathrm{~L}^{-1} \mathrm{HCl}$. Dissolution and precipitation were repeated three times. After centrifugation, the HA fraction was washed with water until there was a negative test with $\mathrm{AgNO}_{3}$ and dialysed (molecular mass cut-off $1 \mathrm{kDa}$; Spectrapor, USA) and freeze-dried. The elemental composition of the HA was characterized using a $\mathrm{CHN}$ analyser (Perkin-Elmer 1483; Perkin-Elmer, Norwalk, CT, USA) and mineralized in a muffle furnace at $750{ }^{\circ} \mathrm{C}$ for 
$8 \mathrm{~h}$ for the ash content measurement. The HA contained $470 \mathrm{~g} \mathrm{~kg}^{-1} \mathrm{C}, 55 \mathrm{~g} \mathrm{~kg}^{-1} \mathrm{~N}, 451 \mathrm{~g} \mathrm{~kg}^{-1} \mathrm{O}$ and $5 \mathrm{~g} \mathrm{~kg}^{-1}$ ash.

The molecular characterization of humic acids was performed by solid-state NMR spectroscopy $\left({ }^{13} \mathrm{C}\right.$-NMR) cross-polarization magic angle spinning (CPMAS). The ${ }^{13} \mathrm{C}$ CPMAS NMR spectrum was acquired with a Bruker AVANCE 300 NMR spectrometer, equipped with a 4-mm-wide bore MAS probe, operating at a ${ }^{13} \mathrm{C}$ resonating frequency of $75.475 \mathrm{MHz}$. Samples (100-200 mg) were packed in $4 \mathrm{~mm}$ zirconia rotors with Kel-Fcaps and were spun at $13 \mathrm{kHz}$. A ${ }^{1} \mathrm{H}$ ramp sequence was used during a contact time of $1 \mathrm{~ms}$ to account for possible inhomogeneity of the Hartmann-Hahn condition. Two thousand scans with 3782 data points were collected over an acquisition time of $25 \mathrm{~ms}$ and a recycle delay of $2.0 \mathrm{~s}$. Bruker Topspin 1.3 software was used to collect and elaborate the spectra. All the free induction decays (FID) were transformed by applying a $4 \mathrm{~K}$ zero filling and a line broadening of $75 \mathrm{~Hz}$. Spectra were integrated in the chemical shift (ppm) resonance intervals: 187-162 (carbonyls of ketones, quinines, aldehydes, and carboxyls), 162-112 (aromatic and olefinic carbons), 112-93 (anomeric carbons), 93-46 (C-O systems, such as alcohols and ethers, $\mathrm{C}-\mathrm{N}$ groups, and complex aliphatic carbons), and $46-0 \mathrm{ppm}$ ( $\mathrm{sp}^{3}$ carbon, mainly methylene and methyl). The hydrophobic/hydrophilic conformation of humic acids was estimated by a dimensionless structural index derived from the relative $\mathrm{C}$ distribution of NMR spectra [35, 36]: the combined relative areas of alkyl (46-0 ppm) and aromatic (162-112 ppm) components, assumed represent the proportion of hydrophobic carbons $(\mathrm{HB})$ were compared to the areas in intervals related to polar groups $(187-162,112-46)$ indicating the proportion of hydrophilic carbon (HI). The hydrophobic index $(\mathrm{HB} / \mathrm{HI})$ was then calculated. The total acidity was obtained by acid-base titration curves of humic acid. One sample of humic acid from vermicompost was used to perform two independent titrations (two repetitions). Suspensions of LHA were prepared in $0.01 \mathrm{~mol} \mathrm{~L} \mathrm{NaCl}$ by diluting $25.00 \mathrm{~mL}$ of the stock suspension with $25.00 \mathrm{~mL}$ of $0.01 \mathrm{~mol} \mathrm{~L} \mathrm{NaCl}$. This dilution was made directly in the titration vessel, resulting suspensions $500 \mathrm{mg} \mathrm{L}^{-1}$ of like HA from vermicompost. Titrations were performed from pH 3.0 to 11.5 with the standard $0.1 \mathrm{~mol} \mathrm{~L}^{-1} \mathrm{NaOH}$ with the same $\mathrm{NaCl}$ concentration of the like HA suspension that was being titrated. A total of 100 to 120 points (volume of $\mathrm{NaOH}$ and electrode potential, E) was taken. The potential was read only when its variation was smaller

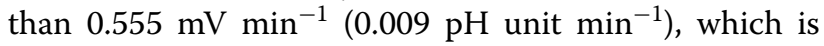
monitored by the drift control of the Orion 900A Thermo $\mathrm{pH}$ meter. The total titration time was around $2.5 \mathrm{~h}$ for each repetition.

\section{Plant assay: dose-response curve}

Seeds of maize (Zea mays L., Dekalb 177) were surface sterilized with $0.5 \%(\mathrm{w} / \mathrm{v}) \mathrm{NaClO}$ for 20 min and kept for $4 \mathrm{~h}$ in water after rinsing. The seeds were placed in paper towels, which were rolled and placed in a germination chamber set at $20-30{ }^{\circ} \mathrm{C}$ (light:dark cycle, $14: 10 \mathrm{~h}$ ), for 3 days. After germination, seedlings with a root length of $2.5 \pm 0.5 \mathrm{~cm}$ were transferred to $400-\mathrm{mL}$ culture vessels containing only $2 \mathrm{mM} \mathrm{CaCl}_{2}$ solution used as control and treatments with acetic acid, humic acids and salicylic acid dissolved in $2 \mathrm{mM} \mathrm{CaCl}_{2}$ solution. The humic acids were solubilized in a $0.1 \mathrm{mM} \mathrm{KOH}$ solution before being dissolved in the $2 \mathrm{mM} \mathrm{CaCl}_{2}$ solution, acetic and salicylic acids were solubilized in ultrapure water and then diluted in solution $2 \mathrm{mM} \mathrm{CaCl}_{2}$ (minimum growth media). Three dose-response curves were obtained with humic acids (HA) $(0,2,4,8$ and $16 \mathrm{mM} \mathrm{C})$, salicylic acid (SA) (0, 0.2, $0.4,0.8$ and $1.2 \mathrm{mM})$, acetic acid (AA) $(4,0,0.4,0.04$ and $0.004 \mathrm{mM})$. The $\mathrm{pH}$ of the solutions was adjusted initially to 5.8 and measured daily. The solutions were aerated with filtered air at low pressure. After 6 days under treatment the seedlings were harvested, and the fresh weight of their roots and shoots were evaluated as well as the surface root area by image analyser software.

Most of the dose-response curves are not linear which implies that at least one of its parameters appears nonlinearly, the parameter appears as exponent, or multiplied or divided by another parameter. The data were linearized and adjusted using the scientific graphing program GraphPad Prism. Several models (logarithmic, exponential, logistic and others) were tested for evaluating the dose-response relationship as a function of time and dose, the $R^{2}$ criterion was used to obtain the best fit model. The dose-response relationship was analysed by nonlinear regression providing the second-order polynomial model as the most appropriate model for the evaluated parameters. For the three treatments with acetic acid, salicylic acid and humic acids, the second-order exponential model provided the best fit according to $R^{2}$. The derivation of the adjusted model allowed a more detailed analysis of the data to evaluate the behaviour of acids.

The statistical design used was completely randomized with five treatments corresponding to acid doses, and three repetitions per treatment.

\section{Intracellular pH measurement with BCECF-AM (2', $7^{\prime}$-bis-(2-carboxyethyl)-5-(and 6)-carboxyfluorescein(-acetoxymethyl ester)}

Two experiments were carried out for intracellular $\mathrm{pH}$ measurement using the BCECF-AM probe. In the first assay, the roots were grown at minimum medium $(\mathrm{mM}$ $\mathrm{CaCl}_{2}$ ) supplemented or not (control) with humic acids 
at $4 \mathrm{mM} \mathrm{C} \mathrm{L}^{-1}$. The $\mathrm{pH}$ of growth solution was adjusted to 4,7 and $9.00 \pm 0.01$ with drops of $1 \mathrm{M} \mathrm{HCl}$ or $\mathrm{NaOH}$. After $48 \mathrm{~h}$ of treatment the root tip was manually cut and immersed in phosphate buffer solution in $0.5 \mathrm{~mL}$ vials (Eppendorf). The phosphate buffer solution was discarded by adding $30 \mu \mathrm{M}$ of the BCECF-AM probe (2,7-bis(2-carboxyethyl)-5(and 6)-carboxyfluorescein). After $30 \mathrm{~min}$ of incubation at room temperature, the roots were washed again with phosphate buffer solution and fixed for $24 \mathrm{~h}$ with $4 \%$ formaldehyde solution. Subsequently, the samples were visualized by epifluorescence with fluorescent filter excitation wavelength band range of 450-490 $\mathrm{nm}$ and emission wavelength band of 535-570 ఇm. Root tissue images were captured by the optical microscope Axioplan-Zeiss, coupled to the digital image acquisition system equipped with a ZVS47EC camera keeping the same excitation power for all treatments.

In the second experiment, the humic acids were set at 8 and $16 \mathrm{mM}$ of $\mathrm{C} \mathrm{L}^{-1}$ since these concentrations promoted the largest and the smallest variation in the acidification of the culture medium, respectively, when compared to the control during the 5 days of measurements of $\mathrm{pH}$. We performed additional controls using 0.1 and $4 \mathrm{mM}$ of acetic acid and 0.1 and $1.2 \mathrm{mM}$ of salicylic acid. After 3 days of germination, the maize seedlings were submitted to each treatment for a period of 6 days of growth, then the roots were manually cut with a blade in segments of 3.0 to $4.0 \mathrm{~cm}$ on a Petri dish. The roots were immersed in phosphate buffer solution in $0.5-\mathrm{mL}$ vials (Eppendorf). The phosphate buffer solution was discarded by adding $30 \mu \mathrm{M}$ of the BCECF-AM probe (2,7-bis(2-carboxyethyl)-5(and 6)-carboxyfluorescein). After $30 \mathrm{~min}$ of incubation at room temperature, the roots were washed again with phosphate buffer solution and fixed for $24 \mathrm{~h}$ with $4 \%$ formaldehyde solution. Subsequently, the samples were visualized at the same conditions of previous experiment.

\section{Differential transcription level of genes with RT-qPCR Extraction of total RNA}

1. A sample of $100 \mathrm{mg}$ of fresh root tissues was homogenized with a mortar and pestle in the presence of liquid $\mathrm{N}_{2}$. The homogenate was transferred to new RNAse-free microcentrifuge tubes $(1.5 \mathrm{~mL})$ and the RNA was extracted using the mini-plant RNeasy Qiagen ${ }^{\circledR}$ kit (Germantown, USA). Reverse transcription (RT) followed by polymerase chain reaction (PCR) $1 \mu \mathrm{g}$ of total RNA was used for production of cDNAs. The synthesis was performed using the highcapacity cDNA reverse transcription kit (Applied
Biosystems, USA). A PCR with a gradient temperature $\left(59,60\right.$ and $\left.61{ }^{\circ} \mathrm{C}\right)$ was performed to confirm the specificity of the primers and the actual melting temperature. Electrophoresis in 2.0\% agarose gel with TAE buffer was also performed for the confirmation of PCR products with the specific primers. Primers for the genes SnRK2.2 F GTCGGGACA CCAGCTTACAT R GGATAGGCACCAACAAGC AT R; MDH F AGTCGTTGCGACAACTGATG R TTCCTTTCCATTCCCTCCTT, ZmTUB $\alpha$ F CCG CACCATCCAGTTCGT R CTGGTAGTTGATTCC GCACTTG; ZmTUB $\beta$ F CTACCTCACGGCATC TGCTATTG R GTCACACACACTCGACTTCACG were designed with Primer3 program and its characteristics were evaluated in Oligothech program and after a rigorous analysis, they were synthesized by IDT technology. Confirmation of primers specificity was obtained in a high-resolution gel, which gave single PCR products at the different temperatures tested and with the expected size. Specificity was also confirmed by melting curve performed in StepOne ${ }^{\mathrm{TM}}$ System (Thermo Fisher Scientific, Waltham, MA, USA). The Real-time PCR (RT-qPCR): for statistical validation two independent tests in the thermal cycler StepOne ${ }^{\mathrm{TM}}$ System, with mRNA extracted from the independent experiments, were performed. cDNAs of each experiment were used in quadruplicate for each condition evaluated. The medium for the PCR was prepared as follows (final concentrations): $5 \rho \mathrm{M}$ of the forward primer, $5 \rho \mathrm{M}$ of the reverse primer $(1 \mu \mathrm{L}), 7.5 \mu \mathrm{L}$ of SYBR Green I component (Applied Biosystems ${ }^{\circledR}$ ) and $0.5 \mu \mathrm{L}$ of ultrapure water. $10 \mu \mathrm{L}$ of medium was added to an ELISA plate and $5 \mu \mathrm{L}$ of $\mathrm{cDNA}$ was added. For cDNA dilution curve, the following concentrations were used: 0.2, 2, 20 and $200 \mathrm{ng}$ of cDNA template at the control condition. The whole procedure was performed in a laminar flow using sterile materials that were RNAse free. After the addition of the reagents, the plate was sealed with adhesive and centrifuged gently. The protocol used for the experiment consisted of four steps: (i) program denaturation (10 $\mathrm{min}$ at $95{ }^{\circ} \mathrm{C}$ ); (ii) amplification program and quantification repeated 45 times $\left[10 \mathrm{~s}\right.$ at $95^{\circ} \mathrm{C} ; 5 \mathrm{~s}$ at $61^{\circ} \mathrm{C}$-for both genes (reference and target); $5 \mathrm{~s}$ at $72{ }^{\circ} \mathrm{C}$ with a single fluorescence acquisition mode]; (iii) melting curve program $\left(65-95{ }^{\circ} \mathrm{C}\right.$ with a heating rate of $0.1{ }^{\circ} \mathrm{C} / \mathrm{s}$ with continuum fluorescence acquisition) and (iv) cooling program to lower the temperature to $40{ }^{\circ} \mathrm{C}$. Crossing points (CPs) were obtained and used in the subsequent calculations. CPs are defined as the point at which the fluorescence achieves significantly higher levels than non-specific fluorescence. The rel- 
ative mRNA expression of the genes of interest and the endogenous control [ubiquitin (UBI)] was compared using a nonparametric pairwise fixed reallocation randomization test as previously described [38].

\section{Transcriptional level of transcription factors WRKY}

We use the transcriptomic analysis of maize seedlings treated with $4 \mathrm{mM}$ of $\mathrm{C} \mathrm{L}^{-1}$ of humic acids to analyse the differential expression level of WRKY transcription factors in root maize seedlings with respect to control treatment. For RNA extraction, $100 \mathrm{mg}$ of control roots and HA-treated roots, using the best dose for root growth at $4 \mathrm{mM} \mathrm{C} \mathrm{HA} \mathrm{L}^{-1}$ were macerated in liquid nitrogen. The total RNA of the samples (3 biological replicates per treatment) was extracted with the RNeasy Plant Mini Kit (Qiagen), according to the manufacturer's instructions. Total RNA was quantified using the Nanodrop 1000 spectrophotometer. The RNA was eluted in DEPC-treated water (total amount of 4-10 $\mu \mathrm{g}$ RNA) digested with DNAse and depleted of ribosomal RNA using the GOTAQ ${ }^{\circledR}$ 1-STEP RT-QPCR (PROMEGA). Subsequently, a $1 \%$ free RNAse agarose gel was made to analyse the RNA extracted. Sequencing libraries were prepared using the Whole Transcriptome Analysis kit (Applied Biosystem) according to the manufacturer's protocol. Libraries were sequenced on the Illumina platform by LacTad company, Brazil. To perform bioinformatics analysis of the sequences obtained by RNA-Seq, the reads obtained from the RNA-Seq were analysed to identify ribosomal RNA (rRNA) sequences in two steps: (1) rRNA sequences of Zea mays were downloaded from NCBI and an index file of rRNA was created using Novoalign v3.06.05. (https://www.novocraft. $\mathrm{com} /$ products/novoalign/). Then reads were mapped on index file using Novoalign; (2) all fasta files were converted into Fasta and BLASTN analysis was performed against downloaded rRNA sequences. Identified rRNA sequences were removed and reads were cleaned. Further, quality of all reads was accessed by running the FastQC software [63] and high-quality cleaned reads were aligned on $Z$. mays genome using Novoalign. Gene expression levels were normalized as reads per kilobase of transcript per million mapped reads (RPKM). The differential gene expression between control and inoculated were determined by using Cuffdiff v2.2.1. The genes with differences of at least onefold change along with adjusted $p$-value $($ FDR $) \leq 0.05$ were considered to be significantly differentially expressed. Functional classification analysis was executed with MapMan version 3.6.0RC1 (https:// mapman.gabipd.org/).

\section{Results}

Characterization of humic acids

The ${ }^{13} \mathrm{C}$ CP/MAS NMR spectrum of humic acids is shown in Fig. 1. The high field region in NMR spectrum includes the alkyl-C resonances $(0-45 \mathrm{ppm})$, associated to the presence of aliphatic chains $\left(-\mathrm{CH}_{2}-\right.$ groups) pertaining to various lipid compounds, such as fatty acids, plant waxes and bio-polyesters. Furthermore, the less intense broader shoulders within the $40-50 \mathrm{ppm}$ range, are mainly attributable to the inclusion in the humic fraction of tertiary $(\mathrm{CH})$ and quaternary $(\mathrm{C}-\mathrm{R})$ carbons in assembled rings of sterol derivatives as well as to $\mathrm{CH}$ and $\mathrm{CH}_{2}$ groups in $\beta$ and $\alpha$ position of peptidic moieties [39]. The sharp signals centred at $55.8 \mathrm{ppm}$ combine either the methoxyl substituent on the aromatic rings of guaiacyl and siringyl units in lignin components, as well as the $\mathrm{C}-\mathrm{N}$ bonds in amino acid moieties. The different peaks in the O-alkyl-C chemical shift (60-110 ppm) are conventionally assigned to monomeric units of polysaccharide chains such as cellulose and hemicellulose of plant tissue. The intense signals around $73 \mathrm{ppm}$ is formed by the overlapping resonances of carbon 2, 3, and 5 , in pyranoside structure. The shoulders at $82 \mathrm{ppm}$ derive from the carbon 4 involved in the glycosidic bond with the most deshielded di-O-alkyl anomeric carbon centred at $104.7 \mathrm{ppm}$ in glucose units [35]. The broad bands extended along the aryl-C interval (116-140 ppm) involve the un-substituted and C-substituted phenyl units of different aromatic components, while the signals shown in the phenolic region (140-160 ppm) are indicative of O-bearing carbon 3,4 , and 5 in the aromatic ring of lignin derivatives, carbon 3 and 5 being coupled to methoxyl substituent. Finally, the sharp signal at $173.7 \mathrm{ppm}$ includes all carbonyl and carboxyl groups

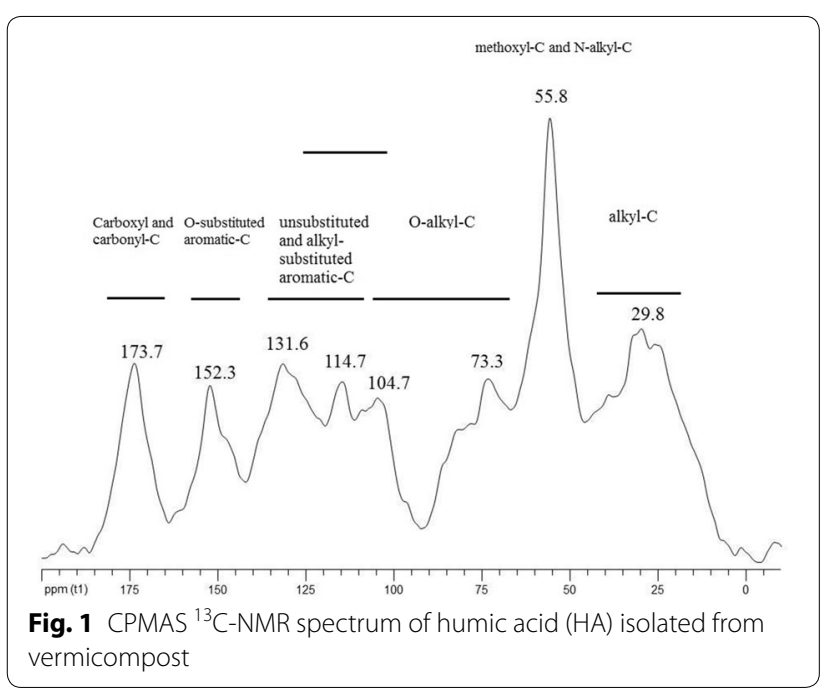


of different components such as aliphatic acids or amino acid moieties. The carbon distributions in the different chemical shift (ppm) intervals showed that alkyl region $(0-50 \mathrm{ppm})$ represents around $23 \%$ of molecular composition of humic acids. The signals attributed to O-alkyl components (60-110) represent $24.6 \%$ and $\mathrm{CH}_{3} \mathrm{O} / \mathrm{CN}$ $16.7 \%$ while aromatic $\mathrm{C}(\mathrm{O}$-aryl +aryl between 110 $160 \mathrm{ppm}$ ) represent $27 \%$ of spectrum. The carboxyl-C signal (160-190 ppm) represents $8.8 \%$ of spectrum area. The total acidity of humic acids was high $2.8 \mathrm{mM}$ and compatible with high $\mathrm{O}$ content determined by elemental analysis and carboxyl-C signal in ${ }^{13} \mathrm{C}$ CPMAS NMR. Humic acids can be considered as polyelectrolyte of weak acids due to the presence of pKas at 3.3, 3.6, 4.8 and 7.5 corresponding to around $2.01 \mathrm{mmol}$ of titratable carboxylic groups per gramme of humic acid according to the titration curve.

\section{Dose-response curve of humic acids, acetic and salicylic acids}

The root growth in response to different concentrations of organic acids is shown in Fig. 2. All organic acids enhanced fresh root weight with respect to control. The quadratic model described the behaviour of root fresh weight in response to concentration of all organic acids despite the high standard deviation (Fig. 2). Humic acids at $4 \mathrm{mM} \mathrm{C} \mathrm{L}^{-1}$ enhanced ca. to $20 \%$ the fresh root weight. The corresponding increase for acetic $\left(0.5 \mathrm{mM} \mathrm{L}^{-1}\right)$ and salicylic $\left(0.4 \mathrm{mM} \mathrm{L}^{-} 1\right)$ acids were around $10 \%$ and $6 \%$ of fresh root weight, in that order. Concentration higher than $4 \mathrm{mM}$ for acetic and $1.2 \mathrm{mM}$ for salicylic acid had toxic effect on plant development (data not shown).

\section{$\mathrm{pH}$ of growth medium}

The $\mathrm{pH}$ variation in the growth medium during the experiment is shown in Fig. 3. The changes in the $\mathrm{pH}$ medium with the time were according the concentration of HA and type and concentration of organic acids (Fig. 3). The higher concentration of HA (16 mM) showed linear drop of pH similar to that of control plants (Fig. 3a). The other HA concentrations promote a rapid drop in $\mathrm{pH}$ followed by stabilization in a significant negative exp model (Fig. 3b). The $0.2 \mathrm{mM}$ salicylic acid promoted a linear decrease of $\mathrm{pH}$ (Fig. 3c) while the other concentrations also followed the negative exp model (Fig. 3d). The lower concentration of acetic acid promotes a linear fall in the $\mathrm{pH}$ medium (Fig. 3e). The other concentrations of acetic acid increased the $\mathrm{pH}$ medium at the initial time of measurement. However, the alkalinization of growth medium was followed by acidification at $0.04 \mathrm{mM}$ in a polynomial
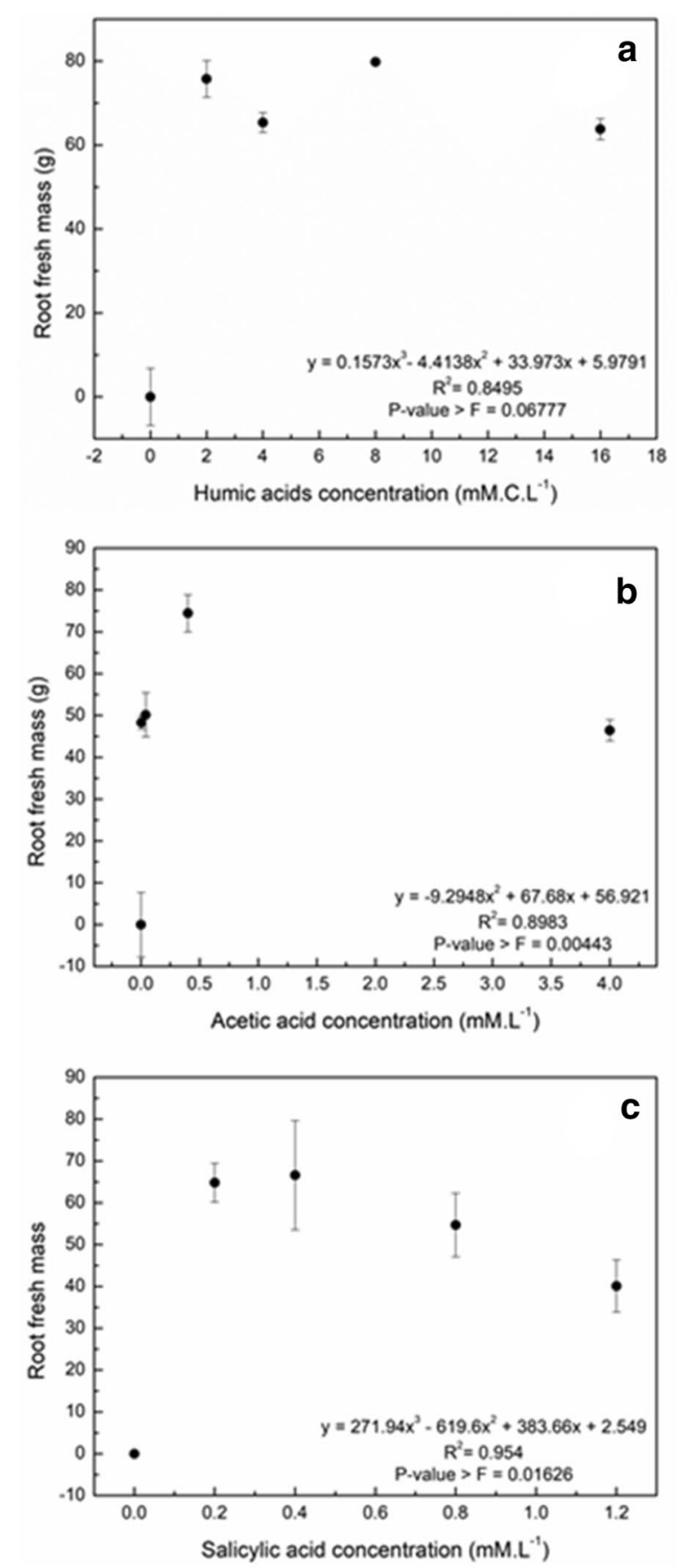

Fig. 2 Dose-response curve of root maize seedlings (fresh root mass, g) treated with different concentrations of organic acids: a humic acids; $\mathbf{b}$ acetic acid; $\mathbf{c}$ salicylic acid

model (Fig. 3f) and a bell-shaped curve at $0.4 \mathrm{mM}$ (Fig. 3g). The alkalinization was not followed by acidification at higher acetic acid concentration $(4 \mathrm{mM})$ showing significant quadratic model behaviour (Fig. 3h). 


\section{Intracellular $\mathrm{pH}$ changes by BCECF-AM probe}

The variation of intracellular $\mathrm{pH}$ of excised maize root-

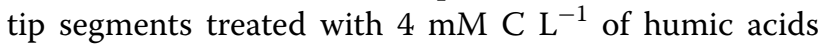
at different external $\mathrm{pH}$ (growth medium) is shown in Fig. 4. At $\mathrm{pH} 4$ and 7 the humic acids induced the epidermal and outer cortex root cells alkalinization with respect to control, as revealed by the enhancement of probe fluorescence signal (Fig. 4b, d). However, at $\mathrm{pH} 9$ a remarkable reduction of the probe fluorescence signal was observed that indicated an intracellular acidification induced by humic acids (Fig. 4f). An opposite trend was observed for control plants (Fig. 4a, c, e). Interestingly, HA-treated roots had shown less uniform fluorescent signal pattern than control. This finding suggests that the different classes of molecules released from the humic suprastructure may modulate cell-to-cell $\mathrm{pH}$-response. In the treatment at increasing humic concentration $(8$ and $16 \mathrm{mM} \mathrm{C} \mathrm{L}^{-1}$ ), the recorded intense fluorescence of probe systems in the control sample provided indirect evidence that intracellular $\mathrm{pH}$ was close to neutrality (Fig. 5c, d vs. Fig. 5a). The significant decrease in probe fluorescence shown at $8 \mathrm{mM} \mathrm{C} \mathrm{L} \mathrm{L}^{-1}$ of dissolved humic molecules correlates with the intracellular acidification with the larger external medium acidification found at the same humic concentration since (Fig. 5c). However, a lower decrease in intracellular $\mathrm{pH}$ was detected at the highest humic concentration (Fig. 5d). The fluorescence probe of root seedlings treated with $0.4 \mathrm{mM}$ of acetic acid (Fig. 5e) was similar to control while the application of $4 \mathrm{mM}$ stimulated a strong cell acidification (Fig. 5f). The treatments with salicylic acid had a comparable intracellular acidification for both tested concentrations (Fig. 5g, h).

\section{Transcriptional level of SnRK2.2, malate dehydrogenase and WRKY transcription factors}

The differential expression of the SnRK2.2 protein kinase genes (serine/threonine kinase related to non-fermentative sucrose SNF) and MDH (malate dehydrogenase) in the roots of maize seedlings according to different concentrations of humic, acetic and salicylic acids is shown in Fig. 6. Although all the applied solutions induced an increase of kinase transcription level with respect to control, a different dose-response trend was revealed by low organic acids and both acetic and salicylic acids showed a minor effect with the application of lower doses and a significant increase in the SnRK2.2 transcription level at larger applied concentration with a 5.7 and threefold improvement with respect to control, respectively. Conversely, the treatment with humic acid promoted a similar level of kinase transcription in the range of 2.75 to threefold with respect to the control, irrespective with the applied concentration (Fig. 6a). Likewise, all treatments induced the relative expression of malate dehydrogenase $(\mathrm{MDH})$ at the same level with respect to control, i.e. around twofold (Fig. 6b) with exception of $4 \mathrm{mM}$ of acetic acid and $1.2 \mathrm{mM}$ salicylic acid that the increase was 5- and 3-fold larger that control level (Fig. 6b). The level of WKRY transcription factors was determined only in treatment with humic acids at concentration of $4 \mathrm{mM} \mathrm{C} \mathrm{L}^{-1}$ (Fig. 7). The most WRKY DNA-binding transcription factors were downregulated by humic acid treatment with respect to control (Fig. 7). However, the WRKY2, WRKY 14, WRKY 39, WRKY 49, WRKY 54, WRKY 56, WRKY 65 and WRKY 74 were upregulated with high transcriptional level with respect to control (Fig. 7).

\section{Discussion}

The topical challenge of modern agriculture is to combine the maintenance of crop yields with lower energetic inputs within changing environmental conditions. In this scenario, the abiotic stresses become prevalent limiting factors that need to be faced with the development of sustainable approaches to protect soil and plants. Preconditioning strategy can be utilized to stimulate the adaptation mechanism and enhance the crop resilience capacity and thus limiting the negative impacts on yield quality and productivity. Priming means to elicit and anticipate the plant tolerance against environmental challenges by improving physiological performance via the application of chemical or biotic agents [37]. Humic acids have been found to act as effective $t$ priming agents against plant abiotic stress [12]. Recycled biomasses as vermicompost can be used to obtain humic isolates able to trigger a typical weak acid stress response in plants, i.e. cytosolic acidification followed by activation of gene response.

Humic acids isolated from vermicompost showed common chemical features usually associated with high biological activity such as phenols and carboxylic functional indicated by the at 56, 130 to 150 and $174 \mathrm{ppm}$ chemical shift in ${ }^{13} \mathrm{C}-\mathrm{CP} / \mathrm{MAS}$ NMR spectrum $[38,39]$. The presence of bioavailable C-carboxyl and O-aryl-C was observed by both NMR spectroscopy and acid-basic titration curve unveiling a chemical behaviour of polyelectrolyte weak acids. At the growth medium $\mathrm{pH}$, undissociated forms of different weak acid groups were found in a wide range of $\mathrm{pK}_{\mathrm{a}}$.

The humic acid suspension at $4 \mathrm{mM} \mathrm{C}$ and $8 \mathrm{mM} \mathrm{C} \mathrm{L} \mathrm{L}^{-1}$ promoted the maize seedlings root growth with respect to control (Fig. 2). The effect of humic acids in root is often dependent on concentration, organic source, plant type and age [1]. The average increase in root dry weight following humic acids application is usually around $20 \%$ in different experimental conditions [40], much smaller than root stimulation 

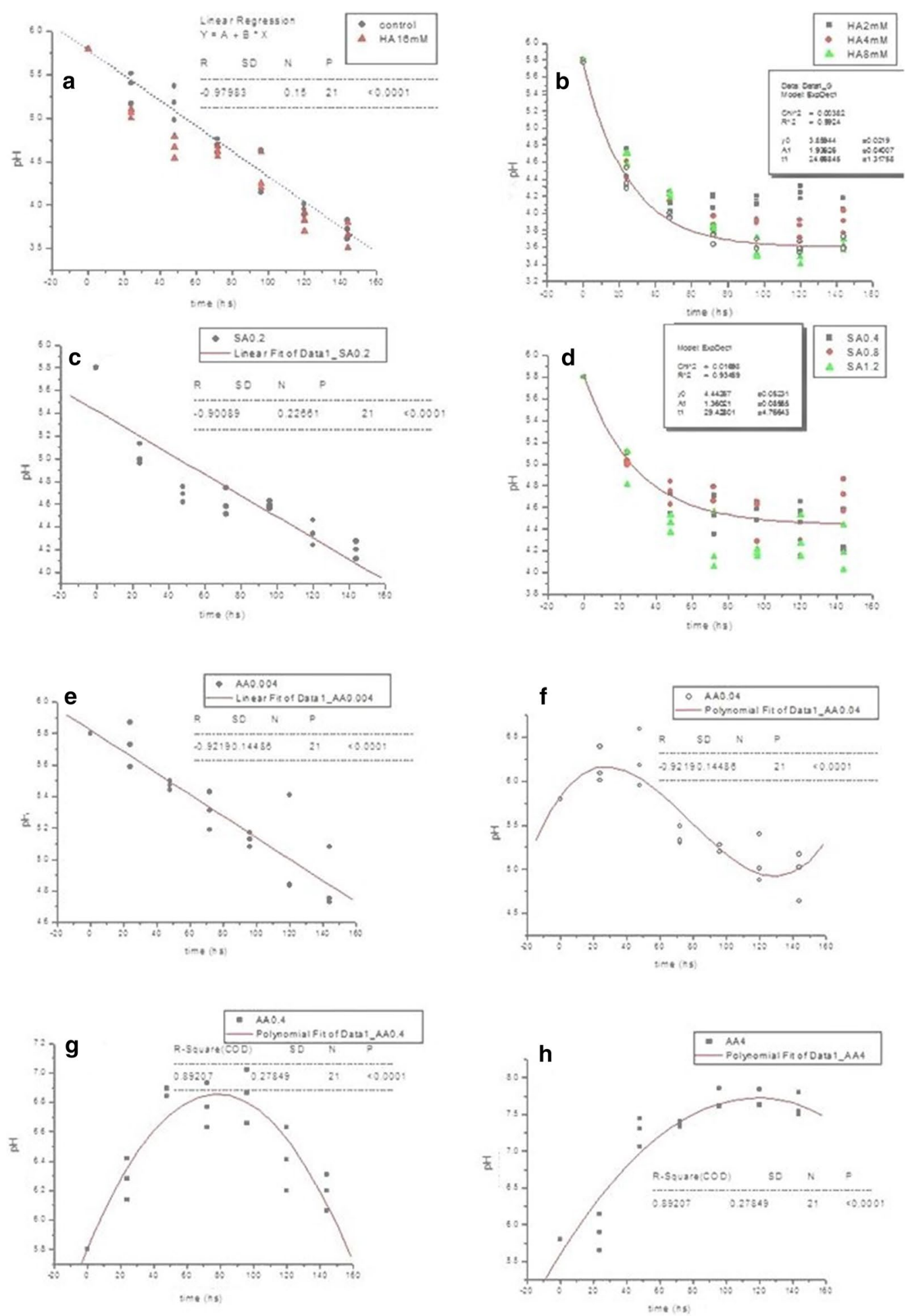

Fig. 3 Changes in pH of root maize seedlings growth medium during the experimental time as a function of different concentrations of organic acids: a humic acids; $\mathbf{b}$ acetic acid; $\mathbf{c}$ salicylic acid 


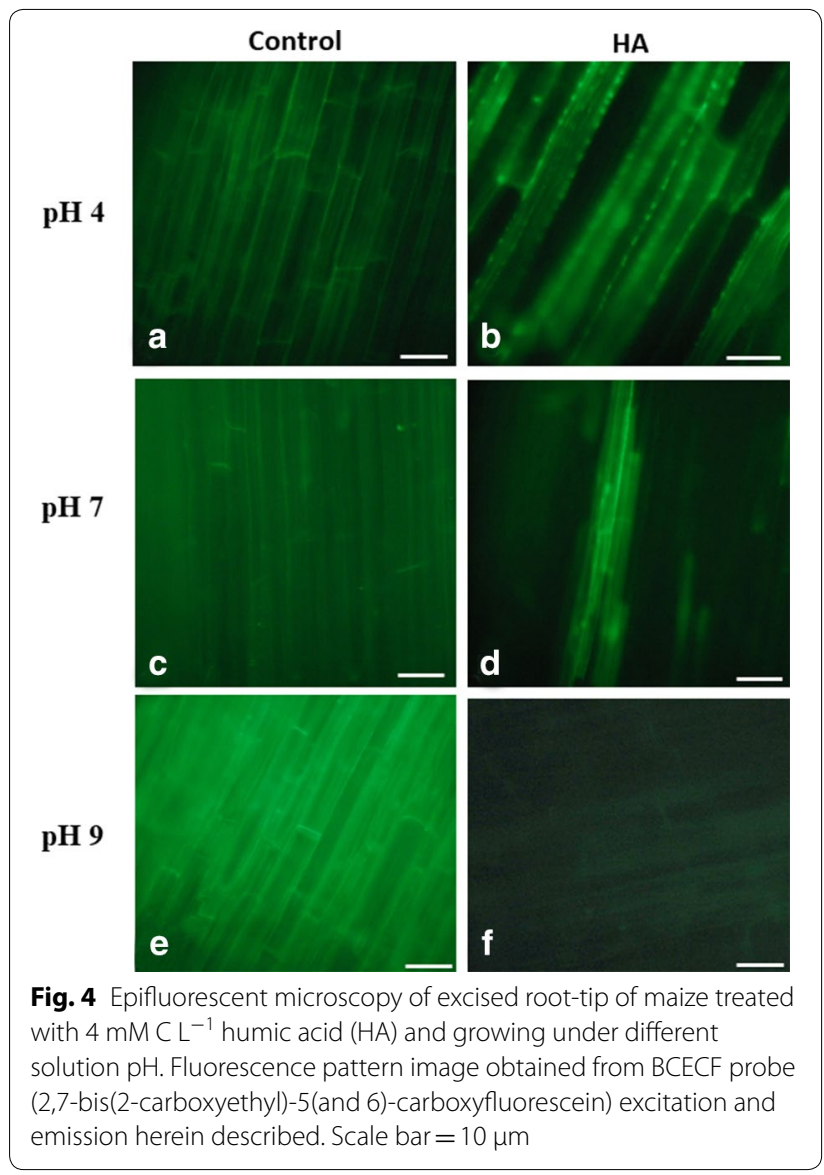

observed in this study (80 to 170\%). Low concentration of both acetic and salicylic acids also promoted root growth with respect to control (Fig. 2). The stimulation associated with acetic acid was related to activation of jasmonate (JA) signalling pathway that confers drought tolerance [33]. Exogenous application of salicylic acid is often related to activation of plant defence, but may also play a role during the plant response to different abiotic stresses with crucial role in the regulation of physiological and biochemical processes during the entire lifespan of the plant [41].

The main short effect of weak acids in plants is cellular $\mathrm{pH}$ decrease by $\mathrm{COOH}$ dissociation as observed in all treatments revealed by BCECF probe (Fig. 2). BCECF$\mathrm{AM} \mathrm{pH}$ probe is a widely used analytical tool based on a fluorescence signal after hydrolysis of the acetoxymethyl ester bond by intracellular esterases [42]. In addition, its fluorescence reflects changes in the intracellular environment determined by the specific accumulation of BCECF in the cytoplasm [43]. The lipophilic weak acids enter the cell solely in their undissociated form, and it is this concentration that determines the magnitude of the $\mathrm{pH}$ change [44]. The effect of organic acids in cell $\mathrm{pH}$

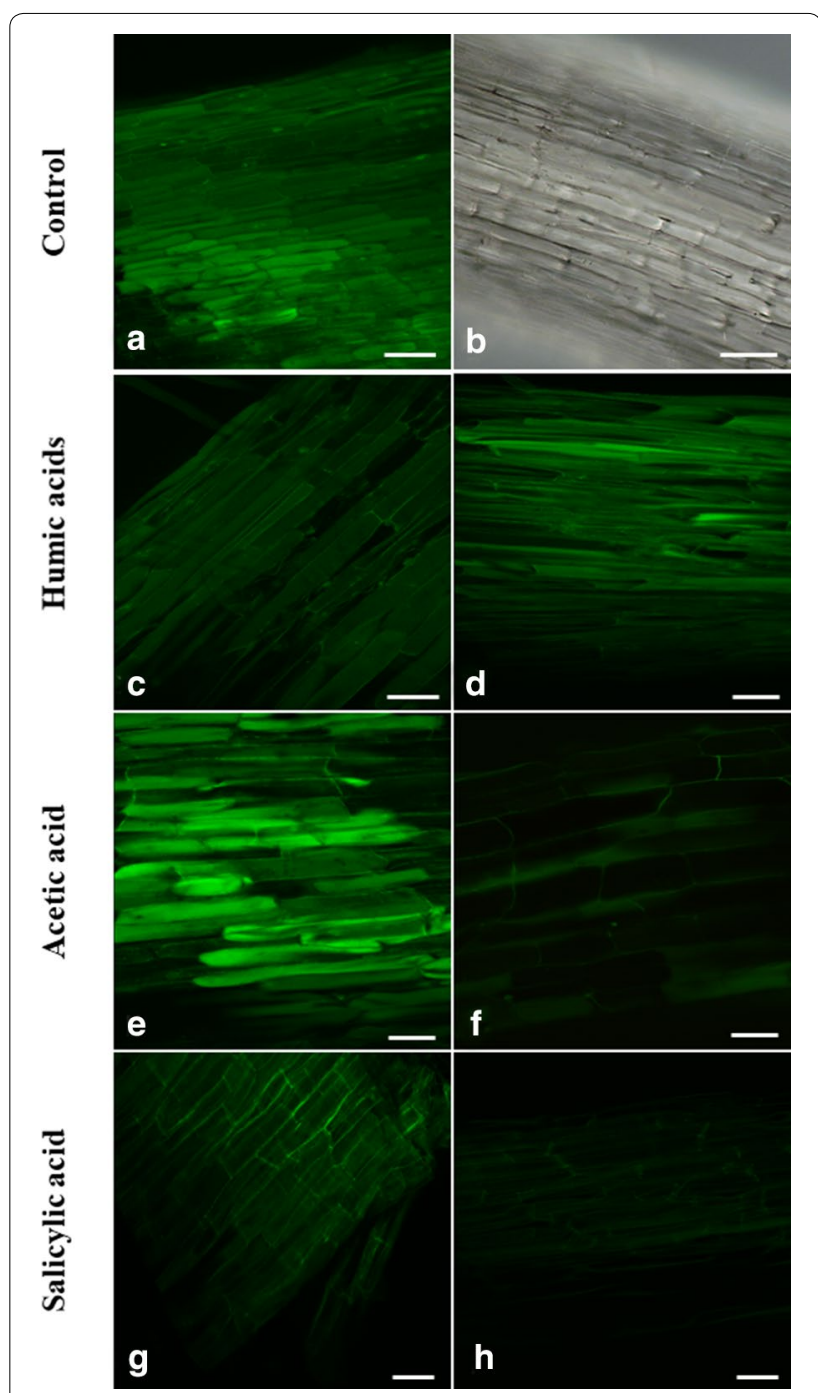

Fig. 5 The fluorescence of BCECF probe

(2,7-bis(2-carboxyethyl)-5(and 6)-carboxyfluorescein) in maize root tips growth at pH 5.8. a Control; b humic acids at $8 \mathrm{mM} \mathrm{CL}^{-1}$ and $\mathrm{C}$ at $16 \mathrm{mM} \mathrm{CL}^{-1}$. d $0.4 \mathrm{mM}$ acetic acid; e $4 \mathrm{mM}$ acetic acid; $\mathbf{f} 0.4 \mathrm{mM}$ salicylic acid; $\mathbf{g} 1.2 \mathrm{mM}$ salicylic acid

drops is transient and dependent on both concentration and chemical nature of organic acids. Here, we observe a lasting-effect of humic acids on cytosolic acidification since the measurement was done after $30 \mathrm{~min}$ of incubation and $24 \mathrm{~h}$ of fixation. The inclusion of phenolic and carboxylic acid functionalities, pertaining to either bioavailable lignin units and saturated, unsaturated, and hydroxylated plant fatty acids, were closely related to the effective bioactivity properties and stress recover responses in plant treatments with vermicompost humic acids [39, 44-47].

There are many interpretations of physiological significance of intracellular acidification. Hagendoom et al. [42] 

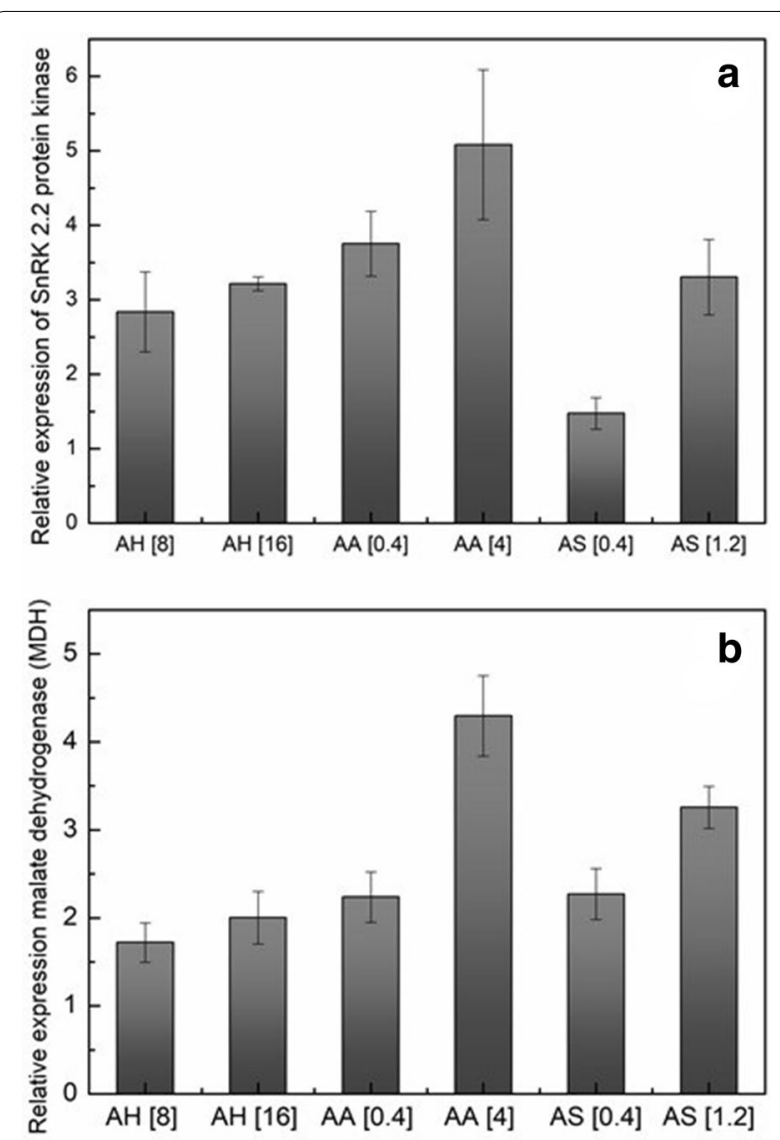

Fig. 6 a Differential transcription of the SnRK2.2 genes (serine/ threonine kinase related to non-fermentative sucrose SNF) and $\mathbf{b}$ $\mathrm{MDH}$ (malate dehydrogenase) measured by RT-qPCR according the treatments: HA humic acids ( 8 and $16 \mathrm{mM} \mathrm{CL}^{-1}$ ); $A$ A acetic acid $(0.4$ and $\left.4 \mathrm{mM} \mathrm{L}^{-1}\right)$; $A S$ salicylic acid $\left(0.4\right.$ and $\left.1.2 \mathrm{mM} \mathrm{L}^{-1}\right)$. The expression was normalized in relation to the control treatment (control $=1)$. The data represent the mean and the bars the standard deviation $(n=3)$ in three independent experiments

showed a correlation between secondary metabolite production and a low cytoplasmic $\mathrm{pH}$ in different plant species. However, cytoplasmic acidification is not necessarily a prerequisite for the induction of secondary metabolite production, but might be part of a metabolic shift that accompanies this production [42]. Pelagio-Flores et al. [47] showed that inoculation with Trichoderma promotes a plant acidification and anthocyanin accumulation (secondary metabolism product) enhancing the plant protection mechanism. The phenolic compounds accumulation in plants treated with humic substances were previously observed as well as the promotion of activity of phenylalanine (tyrosine) ammonia-lyase (PAL/TAL) [48]. This enzyme catalyses the first committed step in the biosynthesis of phenolics by converting phenylalanine to transcinnamic acid and tyrosine to $p$-coumaric acid.

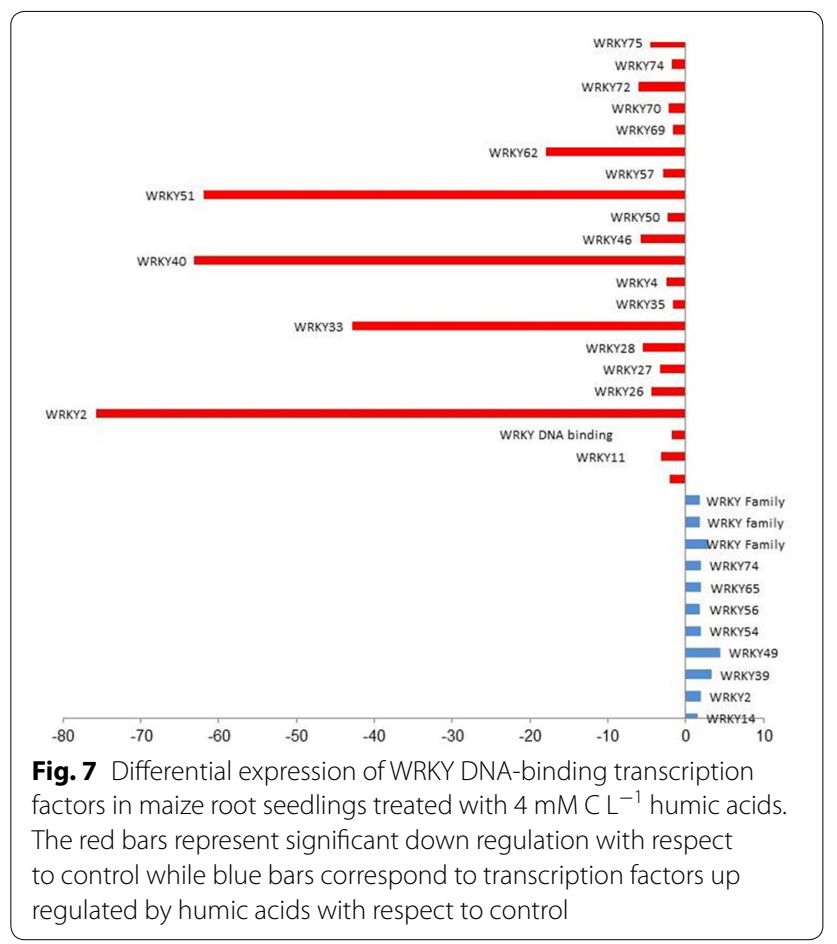

Changes in cytoplasmic $\mathrm{pH}$ occur in response to a wide array of stimuli, including phytohormones [49], chemical elicitors including glycoproteins, pectic enzymes, oligosaccharides, polyene antibiotics, sulfhydryl reagents [50] and polycyclic aromatic hydrocarbons (PAHs) [51]. One of the most acknowledged issues concerning the physiological effect of humic acids is their effects on proton pumps. Humic acids can increase the activity of plasma membrane $\mathrm{H}^{+}$-ATPase $\left(\mathrm{P}-\mathrm{H}^{+}\right.$-ATPase) and vacuolar $\mathrm{H}^{+}$-ATPase $\left(\mathrm{V}-\mathrm{H}^{+}\right.$-ATPase), thus modulating the cellular electrical environment and acting as cell buffer [52]. Furthermore, protons are implicated as a mediator in plant signal transduction with constitutes a key crosspoint in the signalling cascades leading to the activation of defence genes [53]. Cytoplasmic free $\mathrm{H}^{+}$may represent a component of the signalling network, which interacts with other types of second messengers such as changes in cytosolic calcium and membrane potential [50].

The increase in free cytosolic calcium concentration $\left[\mathrm{Ca}^{2+}\right]_{\text {cyt }}$ is an early signalling physiological response to humic acids application [54] which imply a signal transduction by phosphorylation pathways. Protein phosphorylation and dephosphorylation are an important reversible post-translational modification that causes inactive proteins to become active and vice-versa [55]. Protein phosphorylation has a prominent role in cell signalling and protein kinases and phosphatases, which, respectively, catalyse phosphorylation and dephosphorylation of specific substrates. Plant protein kinases 
regulate multiple processes, including metabolism, cell cycle, stress and hormone responses [55]. The SNFrelated kinases are considered to be crucial elements of transcriptional, metabolic and developmental regulation in response to stress since one factor crucial for development and survival is the control of energy balance [56]. In the present study, the transcriptional level of SnRK2 was higher than control in plants treated with humic acids (Fig. 6). SnRK2 is a central integrator of stress and energy modulating the expression of more than 1000 genes through phosphorylation of various transcription factors including several WRKY transcription factors (TFs) [57]. Plant genomes contain a large number of TFs belong to a few large multigene families, e.g. NAC, bZIP and WRKY. The WRKY is a class of DNA-binding protein TFs that play a major role in plant defence to abiotic and biotic stresses. WRKY33 is one of the upregulated genes found in transcriptome of plants exposed to acidic apoplastic $\mathrm{pH}$ [58] as well as by cytosolic acidification [59]. These transcription factors were down regulated by maize seedling treatment with humic acids (Fig. 7). It was demonstrated that the WRKY23 is needed for proper root growth and development by stimulating the local biosynthesis of flavonols, a polyphenol that act as endogenous regulators of auxin transport [60]. WRKY45 was involved in phosphate starvation response and on the activation of high-affinity Pi transporters and lateral root emergence [61]. The results of transcriptional analyses showed that all these TFs were downregulated by exposure to humic acids. It was previously demonstrated that humic acids can induce the differential expression of high-affinity $\mathrm{Pi}$ transporters even in high Pi concentration [62]. AtWRKY45 mediates the expression of a transporter needed for phosphate acquisition, providing an insight into how WRKYs manage plant tolerance to soil abiotic stress [61]. It was previously observed that were also involved in the regulation of phenylpropanoid pathways by the production of a variety of phenolic compounds $[63,64]$ may also directly or indirectly affect flux through the phenylpropanoid pathway, resulting in altered biosynthesis of other phenolicbased compounds, e.g. flavonoids, lignans, etc. [3, 65]. This interaction is further supported by report showing that osmotic stress can induce the activation of a SAinduced protein kinase [66]. The effect of humic acids on phenylpropanoid pathway was mentioned above as well as in protein kinases.

Finally, the mechanisms contributing to intracellular $\mathrm{pH}$ regulation in plant cells can be simplified into two types. A metabolic-based regulatory mechanism (i.e. the biochemical pH-stat) is a critical component in cytoplasmic $\mathrm{pH}$ regulation). It relies on metabolites acting as strong $\mathrm{pH}$ buffers and $\mathrm{pH}$-dependent metabolic reactions such as the carboxylation and decarboxylation of organic acids such as oxaloacetate or malate to consume or generate $\mathrm{H}^{+}$. The concept of control of cytoplasmic $\mathrm{pH}$ via metabolite interconversions is the well-known carboxylation $\left(\mathrm{OH}^{-}\right.$-consuming) enzyme PEP carboxylase activity that is stimulated by high $\mathrm{pH}$ and the decarboxylating $\left(\mathrm{OH}^{-}\right.$-producing) malic enzyme activity that is stimulated by more acidic conditions [67]. Malate dehydrogenase is one of the critical enzymes in malate metabolism. The enhancement of the relative transcriptional level of MDH was observed in all treatments (Fig. 6).

The second regulatory mechanism, defined as the biophysical pH-stat, is the membrane transport of $\mathrm{H}^{+}$ between the cytoplasm and the two main acidic compartments, the apoplast and vacuole [52]. This is primarily facilitated by directly energized $\mathrm{H}^{+}$pumps, including the P-type $\mathrm{H}^{+}$-ATPase (P-ATPase) at the plasma membrane, which pumps $\mathrm{H}^{+}$into the apoplast, and the $\mathrm{V}$-type $\mathrm{H}^{+}$-ATPase (V-ATPase) at the tonoplast, along with a $\mathrm{H}^{+}$-pyrophosphatase $\left(\mathrm{H}^{+}\right.$-PPase), pumps $\mathrm{H}^{+}$into the vacuole [52]. Humic acids from different sources promoted a concerted activation of all these proton pumps [52] and enhance nitric oxide production in lateral maize roots $[26,27]$. Since $\mathrm{pH}$ reduction is essential for the non-enzymatic synthesis of $\mathrm{NO}$ from $\mathrm{NO}_{2}^{-}$, regulation of pumps by humic acids may be necessary during weak acids response in maize root tips.

\section{Conclusion}

We observed that humic acids similar to other organic acids showed a typical weak acids response. Humic acids induced cytosolic acidifications was reported by BCEBC probe and it has been suggested that they could be involved in elicitor signalling cascades since the cell sensor energy SnRK1 was activated as well as WRKY TFs. The weak acid stress activation can contribute to the formation of shortterm stress imprints. It has been demonstrated that cell priming by humic acids involves accumulation of $\mathrm{H}^{+}$in the cytosol either by proton pump activation or by permeation of undissociated carboxyl moieties from humic acids.

\section{Abbreviations \\ CP/MAS ${ }^{13} \mathrm{C}$ NMR: Cross-polarization/magic angle spinning nuclear magnetic resonance of isotope carbon with 13 mass; HA: Humic acids isolated from vermicompost.}

\section{Acknowledgements}

We would like to acknowledge the reviewers for their suggestions.

\section{Authors' contributions}

DCB carried out the experiments that were part of her master's thesis; FLO supervised and conducted the microscopy analysis; DBZ supervised he physiological studies; CPS supervised the real-time PCR (RT-qPCR); RS performed 
the ${ }^{13} \mathrm{C}$ CP/MAS NMR spectrum and data interpretation; LPC conceived the experimental idea, designed the experiment and was responsible for writing the manuscript. All authors read and approved the final manuscript.

\section{Funding}

This work was supported by Fundação Carlos Chagas Filho de Amparo à Pesquisa do Estado do Rio de Janeiro (FAPERJ) Cientista do Nosso Estado programm, Conselho Nacional de Desenvolvimento de Pesquisa e Tecnologia (CNPq) and FINEP-Pluricana Project. DCB received a master fellowship from FAPERJ and this work is part of her thesis.

\section{Availability of data and materials}

Not applicable.

\section{Ethics approval and consent to participate}

This manuscript is an original paper and has not been published in other journals. The authors agreed to keep the copyright rule.

\section{Consent for publication}

The authors agreed to the publication of the manuscript in this journal.

\section{Competing interests}

The authors declare that they have no competing interests.

\begin{abstract}
Author details
${ }^{1}$ Núcleo de Desenvolvimento de Insumos Biológicos para a Agricultura da Universidade Estadual do Norte Fluminense Darcy Ribeiro, Ave Alberto Lamego 2000, Campos dos Goytacazes CEP 28013-602, Brazil. ${ }^{2}$ UFRJ - Universidade Federal do Rio de Janeiro, Instituto de Biodiversidade e Sustentabilidade, Macaé, Rio de Janeiro 27965-045, Brazil. ${ }^{3}$ Centro Interdipartimentale per la Risonanza Magnetica Nucleare (CERMANU), Università di Napoli Federico II, Via Università 100, 80055 Portici, Italy.
\end{abstract}

Received: 13 July 2020 Accepted: 27 September 2020

Published online: 09 December 2020

\section{References}

1. Nardi S, Ertani A, Ornella F. Soil-root cross-talking: the role of humic substances. J Plant Nutr Soil Sci. 2017;180:5-13.

2. Olivares FL, Busato JG, Paula AM, Lima LS, Aguiar NO, Canellas LP. Plant growth promoting bacteria and humic substances: crop promotion and mechanisms of action. Chem Biol Technol Agric. 2017;4(1):30

3. Yakhin OI, Lubyanov AA, Yakhin IA, Brown PH. Biostimulants in plant science: a global perspective. Front Plant Sci. 2017;7:2049.

4. Olk DC, Dinnes DL, Rene Scoresby J, Callaway CR, Darlington JW. Humic products in agriculture: potential benefits and research challenges-a review. J Soils Sediments. 2018;18:2881-91.

5. Olaetxea M, Hita D, García AC, Fuentes M, Baigorri R, Mora V, Garnica M, Urrutia O, Erro J, Angel M, Zamarreño AM, Berbara RL, Garcia-Mina JM. Hypothetical framework integrating the main mechanisms involved in the promoting action of rhizospheric humic substances on plant rootand shoot growth. Appl Soil Ecol. 2018;123:521-37.

6. Abbott LK, Macdonald LM, Wong MTF, Webb MJ, Jenkins SN, Farrell M Potential roles of biological amendments for profitable grain production-a review. Agric Ecosyst Environ. 2018;256:34-50.

7. Shah ZH, Rehman HM, Akhtar T, Alsamadany H, Hamooh BT, Mujtaba T, Daur I, Al Zahrani Y, Alzahrani HAS, Ali S, Yang SH, Chung G. Humic substances: determining potential molecular regulatory processes in plants. Front Plant Sci. 2018;9:263.

8. Pukalchik M, Kydralieva K, Yakimenko O, Fedoseeva E, Terekhova V. Outlining the potential role of humic products in modifying biological properties of the soil-a review. Front Environ Sci. 2019;7:80.

9. Seneviratne SI, Nicholls N, Easterling D, Goodess CM, Kanae S, Kossin J, Luo Y, Marengo J, Mclnnes K, Rahimi M, Reichstein M, Sorteberg A, Vera C, Zhang $X$. Changes in climate extremes and their impacts on the natural physical environment. In: Field CB, Barros V, Stocker TF, Qin D, Dokken DJ, Ebi KL, Mastrandrea MD, Mach KJ, Plattner GK, Allen SK, Tignor M, Midgley PM, editors. Managing the risks of extreme events and disasters to advance climate change adaptation. A special report of Working
Groups I and II of the Intergovernmental Panel on Climate Change (IPCC). Cambridge: Cambridge University Press; 2012. p. 109-230.

10. Kinoshita T, Seki M. Epigenetic memory for stress response and adaptation in plants. Plant Cell Physiol. 2014;55:1859-63.

11. Nguyen HM, Sako K, Matsui A, Suzuki Y, Mostofa MG, Ha CV, et al. Ethanol enhances high-salinity stress tolerance by detoxifying reactive oxygen species in Arabidopsis thaliana and rice. Front Plant Sci. 2017;8:1001.

12. Canellas LP, Canellas NOA, Irineu LESDS, Olivares FL, Piccolo A. Plant chemical priming by humic acids. Chem Biol Technol Agric. 2020. https:// doi.org/10.1186/s40538-020-00178-4.

13. Pandolfi C, Macuso S, Shabala S. Physiology of acclimation to salinity stress in pea (Pisum sativum). Environ Exp Bot. 2012;84:44-51.

14. Piccolo A, Spaccini R, Drosos M, Vinci G, Cozzolino V. The molecular composition of humus carbon: recalcitrance and reactivity in soils. In: García C, Nannipieri P, Hernandez T, editors. The future of soil carbon, Chapter 4. London: Academic Press; 2018. p. 87-124.

15. Masoom H, Courtier-Murias D, Farooq H, Soong R, Kelleher BP, Zhang C, et al. Soil organic matter in its native state: unravelling the most complex biomaterial on earth environ. Sci Technol. 2016;50:1670-80.

16. Orlik M. Introduction to the dynamic self-organization of chemical systems. ChemTexts. 2017;3:12

17. Colombo C, Palumbo G, Angelico R, Cho HG, Francioso O, Ertani A, Nardi S. Spontaneous aggregation of humic acid observed with AFM at different pH. Chemosphere. 2015;138:821-8.

18. Chilom G, Rice JA. Structural organization of humic acid in the solid state. Langmuir. 2009;25(16):9012-5.

19. Nardi S, Panuccio MR, Abenavoli MR, Muscolo A. Auxin-like effect of humic substances extracted from faeces of Allolobophora caliginosa and A. rosea. Soil Biol Biochem. 1994;26:1341-6.

20. Muscolo A, Cutrupi S, Nardi S. IAA detection in humic substances. Soil Biol Biochem. 1998;30:1199-201.

21. Pizzeghello D, Nicolini G, Nardi S. Hormone-like activity of humic substances in Fagus sylvaticae L. forests. N Phytol. 2001;151:647-57.

22. Pizzeghello D, Nicolini G, Nardi S. Hormone-like activities of humic substances in different forest ecosystems. N Phytol. 2002;155:393-402.

23. Mora V, Bacaicoa E, Zamarreno AM, Aguirre E, Garnica M, Fuentes M, Garcia-Mina JM. Action of humic acid on promotion of cucumber shoot growth involves nitrate-related changes associated with the root-toshoot distribution of cytokinins, polyamines and mineral nutrients. J Plant Physiol. 2010;167:633-42.

24. Pizzeghello D, Francioso O, Ertani A, Muscolo A, Nardi S. Isopentenyladenosine and cytokinin-like activity of different humic substances. J Geochem Explor. 2013;129:70-5.

25. Zandonadi DB, Matos CRR, Castro RN, Spaccini R, Olivares FL, Canellas LP. Alkamides: a new class of plant growth regulators linked to humic acid bioactivity. Chem Biol Technol Agric. 2019;6:23.

26. Zandonadi DB, Santos MP, Dobbss LB, Olivares FL, Canellas LP, Binzel ML, Okorokova-Façanha AL, Façanha AR. Nitric oxide mediates humic acids induced root development and plasma membrane $\mathrm{H}^{+}$-ATPase activation. Planta. 2010;231:1025-36.

27. Mora V, Baigorri R, Bacaicoa E, Zamarreño AM, García-Mina JM. The humic acid-induced changes in the root concentration of nitric oxide, IAA and ethylene do not explain the changes in root architecture caused by humic acid in cucumber. Environ Exp Bot. 2012;76:24-32.

28. Nardi S, Pizzeghello D, Ertani A. Hormone-like activity of the soil organic matter. Appl Soil Ecol. 2018;123:517-20.

29. Scaglia B, Nunes RR, Rezende MOO, Tambone F, Adani F. Investigating organic molecules responsible of auxin-like activity of humic acid fraction extracted from vermicompost. Sci Total Environ. 2016;562:289-95.

30. García AC, et al. Relação Estrutura-Propriedade-Função em Substâncias Húmicas para Explicar a Atividade Biológica em Plantas. Sci Rep. 2016;6:20798. https://doi.org/10.1038/srep20798.

31. Muscolo A, Sidari M, Nardi S. Humic substance: relationship between structure and activity. Deeper information suggests univocal findings. J Geochem Explor. 2013;129:57-63.

32. Guo ZP, Olsson L. Physiological responses to acid stress by Saccharomyces cerevisiae when applying high initial cell density. FEMS Yeast Res. 2016. https://doi.org/10.1093/femsyr/fow072.

33. Kim J-M, To TK, Matsui A, Tanoi K, Kobayashi NI, Matsuda F, Habu F, Ogawa D, Sakamoto T, Matsunaga S, Bashir K, Rasheed S, Ando M, Takeda H, Kawaura K, Kusano M, Fukushima K, Endo TA, Kuromori T, Ishida J, 
Morosawa T, Tanaka M, Torii C, Takebayashi Y, Sakakibara H, Ogihara Y, Saito K, Shinozak K, Devoto A, Seki M. Acetate-mediated novel survival strategy against drought in plants. Nat Plants. 2017;3:17097.

34. Utsumi Y, Utsumi C, Tanaka M, Ha CV, Takahashi S, Matsui A, Matsunaga TM, Matsunaga S, Kanno Y, Seo M, Okamoto Y, Moriya E, Seki M. Acetic acid treatment enhances drought avoidance in cassava (Manihot esculenta (rantz). Front Plant Sci. 2019;10:521

35. Yuan S, Lin HH. Role of salicylic acid in plant abiotic stress. Z Naturforsch. 2008:63:313-20.

36. Faize L, Faize M. Functional analogues of salicylic acid and their use in crop protection. Agronomy. 2018;8:5

37. Agathokleous E, Kitao M, Calabrese EJ. Hormesis: a compelling platform for sophisticated plant science. Trends Plant Sci. 2019;24(4):318-27.

38. Aguiar NO, Novotny EH, Oliveira AL, Rumjanek VM, Olivares FL, Canellas LP. Prediction of humic acids bioactivity using spectroscopy and multivariate analysis. J Geochem Explor. 2013;129:95-102.

39. de Aquino AM, Canellas LP, da Silva APS, Canellas NOA, Lima LS, Olivares FL, Piccolo A, Spaccini R. Evaluation of molecular properties of humic acids from vermicompost by ${ }^{13} \mathrm{C}$-CPMAS-NMR spectroscopy and thermochemolysis-GC-MS. J Ann App Pyrol. 2019:141:104634.

40. Rose MT, Patti AF, Little KR, Brown AL, Jackson WR, Cavagnaro TR. A meta-analysis and review of plant-growth response to humic substances: practical implications for agriculture. Adv Agronom. 2014;124:37-89.

41. Rivas-San Vicente M, Plasencia J. Salicylic acid beyond defence: its role in plant growth and development. J Exp Bot. 2011;62(10):3321-38.

42. Hagendoom MJM, Wagner AM, Segers C, van der Plas LHW, Oostdam A, van Walraven HS. Cytoplasmic acidification and secondary metabolite production in different plant cell suspensions: a comparative study. Plant Physiol. 1994;106:723-30.

43. Horn MA, Meadows RP, Apostol I, Jones CR, Gorenstein DG, Heinstein PF. Effect of elicitation and changes in extracellular pH on the cytoplasmic and vacuolar pH of suspension-cultured soybean cells. Plant Physiol. 1992:98:680-6

44. Felle $H$, Johannes $E$. The regulation of proton/amino acid symport in Riccia fluitans L. by cytosolic $\mathrm{pH}$ and proton pump activity. J Exp Bot. 1991:41:587-92.

45. Aguiar NO, Medici LO, Olivares FL, Dobbss LB, Torres-Netto A, Silva SF, Novotny EH, Canellas LP. Metabolic profile and antioxidant responses during drought stress recovery in sugarcane treated with humic acids and endophytic diazotrophic bacteria. Ann Appl Biol. 2016;168:203-13.

46. Martinez-Balmori D, Spaccini R, Aguiar NO, Novotny EH, Olivares FL, Canellas LP. Molecular characteristics of humic acids isolated from vermicomposts and their relationship to bioactivity. J Agric Food Chem. 2014:62:11412-9.

47. Pelagio-Flores R, Esparza-Reynoso S, Garnica-Vergara A, López-Bucio J, Herrera-Estrella A. Trichoderma-induced acidification is an early trigger for changes in arabidopsis root growth and determines fungal phytostimulation. Front Plant Sci. 2017;8:822.

48. Schiavon M, Pizzeghello D, Muscolo A, Vaccaro S, Francioso O, Nardi S. High molecular size humic substances enhance phenylpropanoid metabolism in maize (Zea mays L.). J Chem Ecol. 2010;36:662-9.

49. Gehring CA, Irving HR, Parish RW. Gibberellic acid induces cytoplasmic acidification in maize coleoptiles. Planta. 1994;194:532-40.

50. Mathieu Y, Lapous D, Thomine S, Laurière C, Guern J. Cytoplasmic acidification as an early phosphorylation-dependent response of tobacco cells to elicitors. Planta. 1996;199:416-24.

51. Zhan X, Yi X, Yue L, Fan X, Xu G, Xing S. Cytoplasmic pH-stat during phenanthrene uptake by wheat roots: a mechanistic consideration. Environ Sci Technol. 2015;49:6037-44.

52. Zandonadi DB, Canellas LP, Façanha AR. Indolacetic and humic acids induce lateral root development through a concerted plasmalemma and tonoplast $\mathrm{H}^{+}$pumps activation. Planta. 2007:225:1583-95.
53. Felle HH. pH: signal and messenger in plant cells. Plant Biol. 2001;3:577-91.

54. Ramos AC, Olivares FL, Silva LS, Aguiar NO, Canellas LP. Humic matter elicits proton and calcium fluxes and signalling dependent on $\mathrm{Ca}^{2+}$-dependent protein kinase (CDPK) at early stages of lateral plant root development. Chem Biol Technol Agric. 2015;1:1-12.

55. Crozet $P$, Margalha L, Confraria A, Rodrigues A, Martinho C, Adamo M, Elias CA, Baena-González E. Mechanisms of regulation of SNF1/AMPK SnRK1 protein kinases. Front Plant Sci. 2014;5:190.

56. Polge C, Thomas M. SNF1/AMPK/SnRK1 kinases, global regulators at the heart of energy control? Trends Plant Sci. 2007;12(1):20-8.

57. Baena-González E, Rolland F, Thevelein JM, Sheen J. A central integrator of transcription networks in plant stress and energy signalling. Nature. 2007:448:938-42.

58. Lager I, Andréasson O, Dunbar TF, Andreasson E, Escobar MA, Rasmusson AG. Changes in external pH rapidly alter plant gene expression and modulate auxin and elicitor response. Plant Cell Environ. 2010;33:1513-28.

59. Westphal L, Strehmel N, Eschen-Lippold L, Nicole Bauer N, Westermann B, Rosahl S, Scheel D, Lee J. pH effects on plant calcium fluxes: lessons from acidification-mediated calcium elevation induced by the $\gamma$-glutamylleucine dipeptide identified from Phytophthora infestans. Sci Rep. 2019;9:4733.

60. Grunewald W, De Smet I, Lewis DR, Löfke C, Jansen L, Goeminne G, Bosschea RV, Karimi M, De Rybel B, Vanholme B, Teichmann T, Boerjan W, Van Montagu MCE, Gheysenc G, Mudaye GK, Friml J, Beeckman T, et al. Transcription factor WRKY23 assists auxin distribution patterns during Arabidopsis root development through local control on flavonol biosynthesis. PNAS. 2012;109(5):1554-9.

61. Wang H, Xu Q, Kong YH, Chen Y, Duan JY, Wu WH, Chen YF. Arabidopsis WRKY45 transcription factor activates PHOSPHATE TRANSPORTER1;1 expression in response to phosphate starvation. Plant Physiol. 2014;164:2020-9.

62. Jindo K, Mazzei PL, Olivares FL, Piccolo A, Canellas LP. Phosphorus speciation and high-affinity transporters are influenced by humic substances. J Plant Nutr Soil Sci. 2016;179:206-14.

63. Naoumkina MA, He X, Dixon RA. Elicitor-induced transcription factors for metabolic reprogramming of secondary metabolism in Medicago truncatula. BMC Plant Biol. 2008:8:132.

64. Guillaumie S, Mzid R, Méchin V, Léon C, Hichri I, Destrac-Irvine A, Claudine Trossat-Magnin C, Delrot S, Lauvergeat V. The grapevine transcription factor WRKY2 influences the lignin pathway and xylem development in tobacco. Plant Mol Biol. 2010;72:215

65. Besseau S, Hoffmann L, Geoffroy P, Lapierre C, Pollet B, Legrand M. Flavonoid accumulation in Arabidopsis repressed in lignin synthesis affects auxin transport and plant growth. Plant Cell. 2007;19:148-62.

66. Mikolajczyk M, Awotunde OS, Muszynska G, Klessig DF, Dobrowolska G. Osmotic stress induces rapid activation of a salicylic acid-induced protein kinase and a homolog of protein kinase ASK1 in tobacco cells. Plant Cell. 2000;12:165-78.

67. Smith FA, Raven JA. Intracellular pH and its regulation. Annu Rev Plant Physiol. 1979:30:289-311.

\section{Publisher's Note}

Springer Nature remains neutral with regard to jurisdictional claims in published maps and institutional affiliations. 